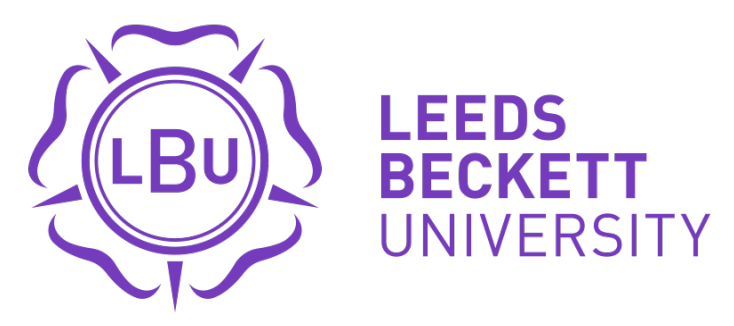

Citation:

Nunn, A (2012) The political economy of competitiveness and social mobility. British Politics, 7 (2). 86 - 110. ISSN 1746-918X DOI: https://doi.org/10.1057/bp.2011.33

Link to Leeds Beckett Repository record:

https://eprints.leedsbeckett.ac.uk/id/eprint/455/

Document Version:

Article (Updated Version)

The aim of the Leeds Beckett Repository is to provide open access to our research, as required by funder policies and permitted by publishers and copyright law.

The Leeds Beckett repository holds a wide range of publications, each of which has been checked for copyright and the relevant embargo period has been applied by the Research Services team.

We operate on a standard take-down policy. If you are the author or publisher of an output and you would like it removed from the repository, please contact us and we will investigate on a case-by-case basis.

Each thesis in the repository has been cleared where necessary by the author for third party copyright. If you would like a thesis to be removed from the repository or believe there is an issue with copyright, please contact us on openaccess@leedsbeckett.ac.uk and we will investigate on a case-by-case basis. 


\title{
The Political ECONOMy OF COMPETITIVENESS AND SOCIAL MOBILITY
}

\begin{abstract}
Social mobility has become a mainstream political and media issue in recent years in the UK. This article suggests that part of the reason for this is that it can serve as a mechanism to discuss policy concerns that appear to be about social justice without questioning important aspects of neo-liberal political economy. The paper charts the policy rhetoric on social mobility under both New Labour and the current Coalition Government. It is argued first that under New Labour the apparent commitment to social mobility was in fact subsumed beneath the pursuit of neo-liberal competitiveness, albeit imperfectly realized in policy. Second, the article suggests that under the Coalition Government the commitment to raising levels of social mobility has been retained and the recently published Strategy for Social Mobility promises that social mobility is what the Coalition means when it argues that the austerity programme is balanced with 'fairness'. Third, however, the Strategy makes clear that the Coalition define social mobility in narrower terms than the previous government. It is argued here that in narrowing the definition the connection with the idea of competitiveness, while still clearly desirable for the Coalition, is weakened. Fourth, a brief analysis of the Coalition's main policy announcements provides little evidence to suggest that even the narrow definition set out in the Strategy is being seriously pursued. Fifth, the international comparative evidence suggests, rather than proves, that any strategy aimed at genuinely raising the level of social mobility would need to give much more serious consideration to narrowing levels of inequality. Finally, it is concluded that when considered in the light of the arguments above, the Strategy for Social Mobility - and therefore 'Fairness' itself - is merely a discursive legitimation of the wider political economy programme of austerity.
\end{abstract}

Keywords

Social mobility, inter-generational mobility, inter-generational justice, social justice, competitiveness.

Acknowledgements

I am very grateful to the two anonymous referees whose comments helped to greatly improve the paper.

\section{INTRODUCTION}

In April 2011 the Coalition Government of the UK published its Strategy for Social Mobility (hereafter the Strategy). Over recent years policy interest in 'social mobility' has risen markedly in the UK and the publication of the strategy is only the latest episode of a longer term interest in the subject. The political and media debate implies that social mobility is only a good thing; that government policy should aim to increase it; and, following from this, that policy is currently not effective in this objective. This article suggests that the attractiveness of social mobility as a policy issue is the result of its appeal to all three major parties because it enables a shared discussion of social justice without questioning the orthodox neo-liberal model of political economy, which suggests that inequalities are tolerable so long as absolute poverty is kept in check and socioeconomic rewards appear to be meritocratically distributed. It is argued here that the policy interest in social mobility can be conceptualized as a central feature of that orthodox model of political economy and that the association of the issue with social justice in the first place is something of a diversion. Rather, it is claimed that policy interest in social mobility is more about increasing productivity and competitiveness through social adjustment to the demands of neo-liberal capitalism. While New Labour attempted this through a mix of market discipline and socialisation, the Coalition so far shows a stronger preference for the extension of market discipline, with less emphasis given to the role of social reproduction. The article then goes on to 
juxtapose the way in which social mobility is conceptualized as a policy issue with some of the international comparative evidence on the subject. Unpicking the policy debate in this way is enlightening because it reveals that the policies now being promoted by the Coalition are in fact likely to be ineffective not just in raising social mobility but also in relation to competitiveness. With these conclusions in place it is argued that the Coalition's interest in social mobility as the defining feature of its 'fairness' agenda, is part of an attempt at discursive legitimation of the wider austerity programme.

\section{RISING POLICY INTEREST IN SOCIAL MOBILITY}

Over recent years policy interest in 'social mobility' has risen markedly. The recent publication of the Strategy is only the latest development. For example, over the last five years there has been intense media (BBC 2007; Giddens 2007; Narey 2007) and political (Hutton 2006; Johnson 2006; Brown 2007; Blunkett 2008; Clegg 2010; Clegg 2011) debate about social mobility in Britain (see Figure 1 and Figure 2 for the increasing prominence of the topic). Indeed, the popular idea that New Labour had failed on this issue may well have contributed in some small way to the change of government in the 2010 General Election. Certainly, the two coalition parties used the issue to critique the incumbent Labour government and continue to frame policy announcements against the assumption that New Labour 'failed' in this regard (Cameron 2010; Carrell 2010).

FIGURE 1: NO. OF ARTICLES IN THE GUARDIAN ON SOCIAL MOBILITY 2000-2011

\section{INSERT FIGURE ONE HERE.}

Source: Guardian Online, query run 19 April, 2011.

The apparent trigger for this political soul searching was the publication of a series of papers within the economic tradition of social mobility research. ${ }^{1}$ These quantitative studies, drawing on the National Child Development Survey and British Birth Cohort Survey, take cohorts born in 1958 and 1970 and consider their achieved social positions compared with that of their fathers. This comparative analysis suggested that comparing between these cohorts intergenerational income mobility had declined (Blanden et al. 2001; Blanden et al. 2004). Blanden and collaborators go on first to compare levels of social mobility in Britain with those elsewhere in Europe and North America and to consider possible statistical explanations for their data. Comparing with elsewhere, Blanden et al. (2005:5-10) show that intergenerational income mobility fell between the two cohorts to levels similar to those in the United States. This placed Britain as a less mobile society than several other comparators, particularly in northern Europe and Canada.

While Blanden et. al's findings do not in any way suggest that social mobility had fallen as a result of the actions of New Labour, they do seem to have coincided with the prominence of this 'impression' in the public debate. However, this is not a clear conclusion from this or other empirical work on social mobility in the UK. Indeed, not only do Blanden and colleagues not say this themselves, others don't even agree that mobility fell for cohorts born in 1958 and 1970. Research in the sociological tradition, drawing on the same data but considering intergenerational movements in the class-occupational hierarchy suggest that rates of social mobility in the UK have been either stable (Goldthorpe 2004; Goldthorpe and Mills 2008) or are very gradually increasing (Lambert, Prandy et al. 2007). Regardless of this, the idea that mobility has fallen, has remained stable or even has increased only slightly does seem counter-intuitive given the establishment of the welfare state, comprehensive education and the apparent opening up of occupational structures in the post-war period, and therefore may account for some of the increased prominence of the issue in political and media debate.

FIGURE 2: PROMINENCE OF SOCIAL MOBILITY IN GOOGLE SEARCHES 
Google Trends, query run 19 April, 2011.

Other reasons for the prominence of the topic might be the rebranding of longer-running debates about inequality, social justice and equality of outcome and opportunity. In particular, social mobility offers an attractive way for the three major parties to debate these issues while sidestepping the important distinction between equality of opportunity and equality of outcome. This then leaves the central assumption of the political centre ground unchallenged: that inequalities are acceptable so long as there are limits to the extent of poverty and scope for individuals to meritocratically achieve their 'potential'. It is possible to dig further to uncover the deeper reasons and implications for the present popularity of the concept of social mobility, through better understanding its linkages to neo-liberal reform. One way of doing so is to place social mobility in the context of the political economy of competitiveness.

\section{The Political ECONOMy of COMPetitiveness}

It has become commonplace to speak of the last thirty to forty years as being dominated by a politics of neoliberal reform, though the term 'neo-liberalism' is subject to considerable definitional ambiguity (Boas and Gans-Morse 2009) $)^{2}$. Here, neo-liberalism denotes a politically motivated development paradigm associated with the pursuit of the interests of capital over labour, and particularly prioritising the interests of finance capital on an increasingly global scale (Nunn 2005). Within this paradigm a variety of policy mixes are tried in different contexts but with the shared objective of increasing the rate of surplus value generation both absolutely - by drawing in more sections of the world's population to the global capitalist economy - and relatively - by intensifying the rate of exploitation of labour power.

It has also become commonplace to think of this political project as having two distinct elements, sometimes referred to as roll-back/first phase and roll-out/second phase (Peck, Tickell et al. 2002; Nunn 2005; Nunn 2007), which are analogous in some respects to Polanyi's identification of the double-movement (Polanyi 1957). The first entails the extension of market discipline, dismantling the legacy social and institutional structures of post-war social democracy. The second focuses on socialisation and the creation of new institutions capable of securing and sustaining enhanced surplus value generation over a longer-period (Nunn 2005; Craig and Cotterell 2007; Nunn 2007; Nunn 2008). This distinction is important because an overemphasis on the first element leads to a confusing and simplistic association of 'neo-liberalism' with reform to extend market power relative to states (as in criticisms of the Washington Consensus for example). In place of this it is preferable to employ a more nuanced assessment of the extent to which active state involvement is encouraged in order to expand the scope of the global capitalist labour market(s) and enhance the generation of surplus value in a pro-market manner (Cammack 2009: 3).

Neo-liberal efforts to increase the rate of surplus generation are fully in line with what Cammack and others have proposed as a 'political economy of competitiveness', which he describes thus:

"The empirical observation that the dynamics of economic, social, political and cultural change in the contemporary world are increasingly shaped by the pursuit and promotion of capitalist competitiveness... Not only are the vast majority of governments around the world explicitly pursuing competitiveness in the global capitalist economy through the reorientation of social and economic policies, but international organisations ranging ... are all busy urging governments everywhere to reform the 'business climate' in order to promote investment and domestic entrepreneurship and stimulate competition." (Cammack 2006: 1)

Competitiveness clearly has geo-political implications at a number of different scalar levels. For instance, competitiveness has traditionally been thought of at the level of the nation-state; as the competitiveness of one state vis-à-vis another. This dimension has clearly not disappeared, but there are new and important differences in the ways that competitiveness should be understood which result from changes in scalar patterns of governance (Hooghe and Marks 2001). First, at the sub-state level it has become commonplace to 
talk of the competitiveness of regions, cities and city-regions, and the UK is certainly no exception to this (Ward and Jonas 2004; Harrison 2007). Second, at the supra-state level many states are becoming enmeshed in a network of regional and inter-regional institutions whose purpose is also, at least partly, to increase competitiveness. Again the UK is undeniably subject to these pressures through its membership of the EU. A quick tour of the various Directorates and EU-wide strategies which include 'soft' governance through setting targets, monitoring progress and peer-surveillance/pressure (the so called Open Method of Coordination) will leave no doubt as to the importance of competitiveness at this level of governance.

The contemporary political economy of competitiveness is about more than just geo-political competition at different levels of multi-levelled governance, though. It is about competitiveness for capital per-se. As such, leading state and supra-state promoters of this development paradigm are often quite happy to promote its adoption elsewhere, even though this is presumably (if one subscribes to the logic) likely to make other states and regions more competitive. For example, the UK state has been at the vanguard of implementing reform for competitiveness at the same time as being a leading proponent of its adoption in other states, either through promoting the agenda via the World Bank in developing countries or in the member-states of an expanded European Union (Nunn 2005: Ch4). Leading institutions such as the IMF, the World Bank, the OECD and the EU have also shared this objective. For instance, the OECD has regularly produced rankings of competitiveness and exhorted governments to do more to secure it, at the same time providing policy advice on how to do so (Cammack 2008). EU leaders, concerned with the effects of policy differences in relation to the current sovereign debt crisis have even proposed a Competitiveness Pact designed to secure compliance with the objective of competitiveness across the Union (Spiegel 2011). Indeed a lack of competitiveness is widely seen as the key problem driving the current Eurozone crisis and therefore increased competitiveness is consequentially seen as the solution.

In this context, the role of governance has changed markedly. The role of political authority - in the image of the competition state - has become the promotion of deep competitiveness, removing state protection of society from the market and replacing it with exposure to market discipline (Cerny 1997). In the UK there has been a long-running attempt to promote competitiveness through social reform to both expand the labour force available for commodification and to increase the productivity of the workforce so that it generates enhanced surpluses (Nunn 2008). The next section describes these attempts before moving on to place the policy debate on social mobility in general, and the recent Strategy in particular, in the context of the political economy of competitiveness.

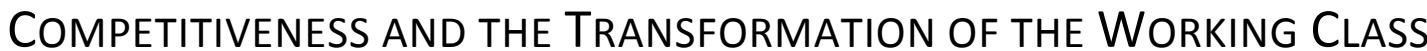

\section{THROUGH SOCIAL MOBILITY}

I have previously argued that there has been a long-term and multi-faceted attempt to transform the working class in the UK to meet the requirements of the political economy of competitiveness (Nunn 2008). This attempt has mirrored the broader construction of neo-liberal hegemony with two-phases: the first being concerned to undermine the corporatism and collective bargaining of the post-war era and extend market discipline. The second phase, which broadly aligned with New Labour's term in government, focused on resolving the problems associated with first phase strategies. These included increasing inequality, labour market polarization (Goos and Manning 2003), increasing insecurity in low paid employment (Gallie 1998; Gallie 2002; Gallie and Paugam 2002) and a significant cyclical workforce moving between employment and unemployment (Smith and Middleton 2007). They also included spatially concentrated pockets of worklessness and deprivation resulting from long-term exclusion from the labour market (Power 1996; Ellen and Turner 1997; Atkinson and Kintrea 2001; Lupton 2003; Houston 2005; DCLG 2006; Sanderson 2007; Fletcher 2008; Nunn 2008: 6; Nunn, Bickerstaffe et al. 2010). 
New Labour thus framed social policy against the need to socialize and contain market discipline. In relation to the labour market two objectives were to the fore: to re-activate the long-term unemployed and inactive population, while also up-skilling the current, future and latent workforces to increase productivity. But these twin objectives were themselves pursued in a slightly sequential and uneven manner. While both trends were clearly evident under New Labour from the start, to begin with, the former objective took precedence, and in some regards remained a more important commitment throughout. After around 2005 there was an increasing realization that without successful action to change the organization of production or to change the structure of the already employed labour force, this was resulting in increasing employment but also increasing in-work poverty and labour market cycling between unemployment and employment. In this early period Active Labour Market Policies were successful in repeatedly activating and pushing unemployed workers into low paid work but this, alongside immigration resulting from EU expansion, acted as a barrier to low-wage employers up-skilling their workforces and adopting higher value-added competitive strategies. As such, around the time that Gordon Brown became Prime Minister, there was a shift, in rhetorical emphasis at least, toward up-skilling. The Leitch Review of Skills (Leitch 2006) and the governments' response to it (Department for Innovation 2007) represented the most high-profile example of this.

The rhetorical commitment to upskilling in pursuit of competitiveness has proven a harder commitment to live up to however, than the prior concern with activation. For example, attempts to integrate the employment and skills systems have not come to fruition, the emphasis in welfare policy remained skewed toward the objective of activation rather than training. For example, indicators of investment in, and take-up of, workforce training remain disappointing in international comparisons (Hogarth, Gambin et al. 2009).

It was in this context however, that the contemporary policy concern with social mobility emerged. The publication of Blanden and colleagues' empirical findings from 2004-6 onwards (Blanden 2004; Blanden 2005; Blanden, Gregg et al. 2005; Blanden and Gibbon 2006; Blanden, Gregg et al. 2006; Blanden, Gregg et al. 2007) coincided with the shift in emphasis in social reform under New Labour and appeared to trigger a significant political interest in the topic of social mobility. Over the next two years social mobility became a key political issue for the three main parties. By the summer of 2005 it was the topic of ministerial key note speeches (IPPR 2005) and in the autumn was even an issue in the Tory Party leadership contest (Anon. 2005). Social mobility was the subject of a major OECD report in 2007 (d'Addio 2007), further high profile ministerial speeches (Johnson 2006), and by 2009 several high profile 'commissions' (Narey 2009; Panel on Fair Access to the Professions 2009) and a White Paper (HM Government 2009). Alongside a speech by former Prime Minister Gordon Brown (2008), the White Paper probably best sets out the thinking of the previous New Labour Government. The next section summarises the way in which social mobility was conceptualized under New Labour.

\section{SOCIAL MOBILITY AND NEW LABOUR}

Brown's speech in June 2008 is by no means the only or first one he gave on the subject, but its length and timing - six months before the publication of the White Paper and in the middle of his time as Prime Minister suggest that it is a good choice for analysis. The speech is significant most of all because it encompasses three key themes: (1) social mobility as competitiveness; (2) competitiveness being for capital in general rather than geo-political advantage per se and (3) aspiration and opportunity being the key to achieving both mobility and competitiveness.

First, it establishes social mobility firmly as a correlate of competitiveness:

"... to get the best results for the individual and the best economy we need to get the best out of people's potential at every step and at every age...imagine what Britain could be if all of the talents of all of the British people, and not just some, could flourish...And what is clear is that as we look ahead it will be the countries where there is hope and ambition for all that will be the great success stories of the global age. Indeed I would 
go further, globalisation will create new opportunities for a new wave of social mobility that Britain must seize." (Brown 2008: paras 19-21).

Social mobility was conceived as a mechanism by which national economies can position themselves in the global economy. The following section of his speech is therefore worth citing at length. It demonstrates an understanding of the links between measured mobility and structural change in society but also shows how he conceived both as a means of shifting the UK working class (encompassing the active and latent workforce) up the Global Division of Labour (GDL):

"... while the post-'45 wave of social mobility came from the changes wrought by the opening up of our national economy, the new wave of social mobility comes from changes that are wrought by opening up the whole global economy. ... the world economy will be twice the size in 2030 than it is today, and it is estimated that as part of that change a billion - one thousand million - new skilled jobs will be created round the world.

And in this new economic environment of global expansion and job creation, as China, India and Asia become consumers as well as producers, there will be major opportunities for those countries that are willing and able to seize these chances. And the issue therefore is not whether there will be change - change will be massive. The issue is who is going to benefit from this great transformation? How can we ensure that increased social mobility means that the benefits of change are widely shared?

And it is all the more important a question because more than ever, while the prizes for success for the individual are great, the consequences of failure are much greater still. In this new world many unskilled workers will become not only poor, but virtually unemployable. But in this new wave also there need be no ceiling on your ability to rise if you can make the effort..

So instead of opportunities limited by the old sheltered national economy ... there will be potentially unlimited opportunities for the forward march of social mobility, opened up by the changes in the wider global economy." (Brown 2008: paras 33-36).

The quotation also reveals a commitment to the classical liberal assumption that competitiveness is in the interests of capital in general rather than just individual states. The promise of globalization in this case is that it is seen as the rising tide that can lift all boats - but that this is dependent on committing to the iron law of competition.

A third notable theme follows from this. The barriers to upward social mobility and the transformation of the working class for greater competitiveness are seen as a lack of aspiration (will) and skills (capacity). In this view the state's role in facilitating competitiveness is seen as the constant reproduction of labour power through rearticulating the vision of the ideal worker and imposing the logic of competitiveness down to the level of the individual:

"And as the possibilities open up once again we must set a national priority to aggressively, relentlessly develop all the potential of all the young people of our country. And it is a commitment that goes beyond education to employment, to the ownership of assets, to enterprise, to culture, and one which is designed to benefit our society as a whole, all of us gaining from each of us having a greater chance to progress.

And social justice in future years may be best expressed as something more than social protection, compensating people with a safety net for what they do not have. Instead it may be better expressed by social mobility, not compensating people for what they don't have, but helping people develop what they do have, their talents, their potential and their ability...

...And it must be a social mobility that we aspire to that is aspirational as well as universal in its approach, a relentless focus on raising the sights of every individual ...." (Brown 2008: paras 38-41) 
What was needed therefore was the generation of commitment to upskilling in pursuit of competitiveness at the level of the individual, the firm, society and the state. In short, what was needed was 'an historic effort to transform aspirations' (Brown 2008: para 67).

This emphasis on aspiration was further underlined in Brown's foreword to the subsequent White Paper: New Opportunities: Fair Chances for the Future (HM Government 2009) where he offered a 'modern definition of social justice' where social protection is replaced with the creation of opportunities 'for everyone to make the most of their potential in a Britain where what counts is not where you come from but what you aspire to become...'. The White Paper then goes on to set out in more detail the context of globalisation and the role that increasing individual competitiveness could have in ensuring a productive working class, able to position the UK to be successful in a competitive global economy. The role of the state is to make a series of detailed interventions at all stages in the life cycle to support individuals and their families from birth to be the most competitive and productive workers possible, defined in terms of flexible and high skilled employment in new

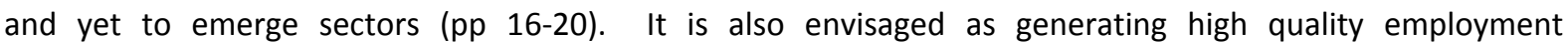
opportunities in delivering increasingly personalised public services to a more demanding and ageing population in which more households have two full-time workers and people work later in their lives (p16).

The view of social mobility that underpinned Brown's pronouncements and the White Paper is as clear a representation as possible of the politics of competitiveness in that social risk is to be dealt with not by protecting individuals, families and communities but enabling them to compete, thereby achieving the maximum possible exposure of labour power to commodification in the formal labour market. Second, the upsurge of social mobility noted in the post-war era was partly generated by the expansion of the state and partly generated by the expansion of the service sector - 'white collar' jobs in the new managerial tasks such as design, organising, logistics, marketing and sales - which accompanied Fordist mass-production. This created a wide variety of new occupations which show up in sociological studies as upward social mobility when compared with parental occupations in manufacturing or agriculture. Following from this, the White Paper envisaged that the prospect of increasing social mobility was about expanding the number of highervalue added jobs through 'industrial activism' (p23-4). State intervention was seen as desireable to improve the organisation of capital as well as to improve the skills of workers and to increase their 'aspirations' to reach the emergent occupations. As such there was a perceived link between relative social mobility - enabling the competitiveness of individuals through skills interventions - and absolute mobility - through moving the whole economy up the GDL (p16-17).

It is also worth pausing at this stage to briefly consider New Labour's high profile commitment to end Child Poverty by 2020 (HM Treasury 2000). This commitment was subject to successive debates and policy reviews as it became clear that progress toward it, while positive, was lagging the required level (HM Treasury 2004; Harker 2006; Nunn 2008: pp5-9, 16-17). The strategy for achieving this objective revolved mainly around a 'work first' commitment to get parents into employment and to subsidise low wages for families with children with tax credits to ensure that 'work pays'. This was perhaps the policy domain in which New Labour did most to effect redistribution, and it is notable that it was undertaken partly by stealth (e.g. hiding it within the tax system) and under the guise of incentivising work in order to protect the wider social policy agenda from reactionist critique, echoing similar attempts by the New Democrats in the United States (Soss and Schram 2007). The objective was again to contain the effects of market discipline to prevent market failure and promote social reproduction in two regards: first by ensuring that families with children were able to offer the maximum participation in the labour market and second ensuring that the widely recognised intergenerational cultures of worklessness were addressed.

At the same time, it is again notable that 'work first' remained the primary route by which these objectives were to be achieved and that the various policy initiatives associated with it tended to attract critique precisely because they did not go far enough to promote mobility within the income distribution and occupational 
hierarchy for key groups such as lone parents and families with one parent in low-wage employment (Brewer, Browne et al. 2011). For example, Lisa Harker's high profile recommendation that Child Poverty targets be pursued through a 'work first plus' route did not lead to any discernible change in policy in that regard and the alternative suggestion (resisted by Harker but promoted by David Freud - later to be welfare advisor to the Conservative party) that conditionality for lone parents be tightened was in fact adopted (Nunn 2008: 15-16). Thus, while it might be argued that the policy commitment to reducing child poverty was where New Labour came closest to articulating and pursuing equality of outcome as opposed to opportunity, that too was rather circumscribed by the imperfectly pursued goal of competitiveness.

\section{THE COALITION's StRATEgy FOR SOCIAL MOBILITY}

The recently published Strategy sets out the Coalition Government's apparent continued commitment to increasing social mobility and how this is to be achieved. This section of the paper looks at how social mobility is defined in the Strategy, the contradictions inherent within this definition and considers how this can inform our understanding of the development paradigm underpinning the Coalition's policy programme.

At the time of the election and then the announcement of public spending cuts the coalition sought to balance the public impression of the imposition of market discipline with the idea of 'fairness', ${ }^{3}$ but failed to fully map out precisely what the idea meant. With the publication of the Strategy such ambiguity can apparently be put to one side; the strategy opens by announcing that fairness, in fact, means social mobility:

"Fairness is one of the values of the Coalition Government, along with freedom and responsibility. There are many ways to think about and define fairness. For us, fairness means everyone having the chance to do well, irrespective of their beginnings.

In a fair society what counts is not the school you went to or the jobs your parents did, but your ability and your ambition. In other words, fairness is about social mobility - the degree to which the patterns of advantage and disadvantage in one generation are passed onto the next. An unfair society is one in which the circumstances of a person's birth determine the life they go on to lead." (HM Government 2011: 11).

The strategy then reaffirms its commitment (first set out in the Coalition Agreement (HM Government 2010)) to place fairness (now to be taken as social mobility) alongside expenditure cuts as the central planks in the programme of government:

"Tackling the financial deficit is the Coalition's most immediate task. But tackling the opportunity deficit creating an open, socially mobile society - is our guiding purpose." (HM Government 2011: Foreword)

"The Coalition Government has made a clear commitment to social mobility as the principal goal of our social policy. This is in itself an important change... we cannot get away from the intense fiscal pressures we face as a country. Failing to reduce the deficit would saddle future generations with enduring public debt and slower growth, threatening social mobility. That creates challenges. We must do more with less. Above all we must do more to promote a fairer society" (HM Government 2011: 11-12).

So social mobility ranks alongside deficit reduction as a policy objective, but it is also presented as if mobility might part of the answer to more sustainable growth through its connection to competitiveness:

"... In our increasingly globalised economy, new opportunities for wealth and income are emerging. A fair society ensures that those opportunities are open to everyone. If talented people are held back, it is not only their life chances that are damaged, but the prosperity of the nation and the dynamism of the economy. Increasing social mobility can drive growth by creating a more highly skilled workforce and putting people in the right jobs for their talents. 
One study has estimated the economic benefits of creating a more highly skilled workforce at up to $f 140$ billion a year by 2050 - an additional 4\% of Gross Domestic Product - along with significant improvement to the underlying rate of growth." (HM Government 2011: 11).

It then goes on to suggest, in contrast to New Labour, that relative rather than absolute mobility is the primary aim for public policy:

"The Government's focus is on relative social mobility. For any given level of skill and ambition, regardless of an individual's background, everyone should have an equal chance of getting the job they want or reaching a higher income bracket." (HM Government 2011: 16).

Following this is an initial outline of the types of policy domain that might be thought to have an influence on social mobility against a 'life cycle approach' covering the 'foundation years' (0-5), 'school years' (5-16), 'transition years' (16-24 years) and 'Adulthood' ( 24 and over). Before discussing in more detail the policy measures to be implemented in each of these domains, is a very short but telling discussion of the 'other factors' that might also influence social mobility. Into this equation are counted economic growth ${ }^{4}$ and greater equality of opportunity with regard to very specific social groups, ${ }^{5}$ and a rather unspecific discussion of health inequalities in childhood. Most revealing of all though, income inequality is rather summarily dismissed in three short paragraphs that are worth quoting in full:

"There is an active debate about the relationship between income inequality and social mobility. Academic studies comparing levels of social mobility in different countries have found a correlation between high levels of income inequality and low levels of social mobility, although some have criticised the validity of this finding. Of course, correlation is not the same as causation. The drivers of social mobility are complex, and income alone does not determine future outcomes.

There are also a number of countries, such as Australia and Canada, that have relatively high levels of income inequality but also high levels of social mobility. Equally, there are some countries that have relatively low levels of income inequality but low levels of socially mobility, such as France.

Of course, income equality is an important goal in its own right, but the challenge in terms of social mobility is to understand the key components of a more mobile society which do not appear to be related to simple measures of income equality." (HM Government 2011: 22)

Despite its brevity, this opening section reveals a great deal about the class politics embodied in the Coalition programme. First, definitional issues. By reducing the scope of the strategy to inter-generational and relative mobility, the strategy appears to suggest a decisive break with the previous government's pursuit of industrial change. This is argued away with the suggestion that existing forecasts suggest that there will be 'more room at the top' in the labour market in any event, regardless of government interventions. This is ofcourse important because without this, relative mobility implies that the upward mobility of some needs to be matched with downward mobility for others. Indeed policies to promote greater relative mobility would need to facilitate these two-way transitions, but there is little in the strategy that suggests that this is a real commitment. Leaving this contradiction aside, and generously assuming that the dismissal of absolute mobility here is because other strategies (e.g. the Plan for Growth (HM Treasury 2011), published at the time of the budget) are to take care of the need to create more high value added jobs, a concern with relative individual mobility is revealing in several other respects.

It suggests that the most important aspect of social mobility is the inculcation of individual competitiveness. In some senses this is a continuation of the previous government's obsession with 'aspiration' as a central barrier to mobility and indeed raising aspirations features as one of the three objectives for 'school years' policies. This is again an interesting area and worthy of comment. Both the present and previous government conceived of the social mobility problem as being related to access to 'professional' jobs. Alan Milburn chaired 
the high profile Commission on Fair Access to the Professions and has been given a similar role with the new government. Much of the fanfare associated with the launch of the Strategy for Social Mobility concerned this issue, and a rather superficial discussion about broadening access to a very limited number of internships (Clegg 2011). Again, all this speaks to the consensus of the desireability of social mobility across the three major parties and its 'motherhood and apple pie' appeal: who could be against creating more equal chances to be lawyers, Doctors or accountants, let alone MPs. The problem comes when the broader class politics are considered.

\section{DISCUSSION AND CONCLUSION}

So the recent publication of the Coalition Government's Strategy for Social Mobility, suggests a continued preoccupation with the issue as an object of government policy but a break with the previous Government's alignment with this as one part of a wider economic strategy which also included a commitment to economic restructuring and upskilling - and therefore absolute alongside relative mobility. This section examines the implications of this shift in light of a small number of concrete policy announcements and the international evidence on the issue.

The focus on relative mobility suggests that not enough able children from working class backgrounds are able to fulfill their potential. This was reinforced by the fanfare afforded to the issue of open advertising and offering payments for internships at the time the strategy was published. Leaving aside the fact that such measures could only ever affect small numbers of people, the evidence also suggests that those social groups at risk of having their status and that of their children devalued by upwardly mobile aspirants from 'lower' social classes are very good at manipulating marginal differences to maintain their advantage. Lucas (2001) shows this persuasively with data on the US: when credentials that previously conferred differential advantage become universal (e.g. specific qualifications) groups that previously held advantage are able to manipulate minute differences (such as school/college type or uncertificated skills and experiences) to maintain their position. Just such a critique might be leveled at Higher Education (HE) in the UK over the last two decades. As the proportion of entrants to the labour market with HE level qualifications has risen, so labour market selection has focused increasingly on the type of institution studied at, the subject of the qualification and other skills apparently gained through unpaid work experience, international volunteering and 'gap' years. ${ }^{6}$ The implication of this is that raising aspirations and increasing educational attainment (major themes in the policy sections of the Strategy throughout the different life stages) will only serve to increase the importance of implicit factors in selection processes for advantageous jobs. Indeed, in Denmark, where society is both considerably more equal and mobile, 'cultural capital' appears to have become more important in determining mobility as parental income has declined in importance (Jæger and Holm 2007).

This leaves the question of how desirable facilitating increased competition for a limited (even if growing) range of professional occupational positions actually is. The assumption underpinning this is that as many young people as possible should be motivated to want to become lawyers, bankers, doctors and the like, because of the apparent higher productivity attached to them. The problem with this is that it assumes that many socially-necessary but low paid occupations are less desirable. It is though highly questionable that the problem for UK society is that young people want to become car mechanics, hair dressers, social care workers or teaching assistants. All these occupations are socially useful and the market for them is unlikely to disappear as a result of international competition (though migration may ofcourse alter the nature of the labour market). Indeed, an ageing society and pressure to expand the portion of the population available for paid employment is likely increase the demand for domestic, personal and caring services. However, all of them would count in 'class' based studies of social mobility as 'working class' occupations and in income based studies toward the lower ends of the income distribution. Rather than encouraging young people to aspire to 'professional' roles it may be more beneficial to question the status, terms, conditions and pay attached to these socially necessary roles. Over the same time period that the income based studies of social mobility 
demonstrate a falling degree of social fluidity, studies of the way in which labour market flexibility has operated show that rising insecurity has been concentrated at the bottom of the pay and occupational hierarchy (Gallie 1998; Gallie and Paugam 2002), that (in work) poverty has increased and the labour market has become more polarized (Goos and Manning 2003). All of this is fully in line with the discussion of rebalancing of social relations in favour of capital discussed above. Put simply: the problem is not so much one of relative individual mobility through the class hierarchy but inequality between socio-economic groups based on their relationship to capital.

Ofcourse, though, the Strategy dismisses the link between mobility and inequality in rather summary terms. This is odd because of all the evidence about correlates between high/low social mobility and other factors in the international comparative literature, inequality is the one variable that shows a positive relationship to the degree of social openness (see Figure 3 for the correlation between inequality and income mobility in selected European and North American countries ${ }^{7}$ ). Put simply, the more equal societies also appear to be more mobile.

FIGURE 3: RELATIONSHIP BETWEEN GINI INEQUALITY AND INTER-GENERATIONAL INCOME PERSISTENCE IN SELECTED EUROPEAN COUNTRIES

INSERT FIGURE THREE HERE

Corak (2006) and OECD (2008).

This is a correlation rather than a statistically causal relationship, as the Strategy is keen to point out. However, there are good reasons to think that the relationship is causal. In a recent study conducted for the Council of Europe (Nunn 2012, forthcoming) the relationship between a range of social, institutional and family-related dynamics and social mobility were compared in countries with a variety of degrees of measured social openness (Denmark, UK, Germany, Italy, Romania). The results of this comparison, which was based on discussions with a range of experts in each country and with an international panel of experts on the topic, suggested that one of the key sets of determinants were original inequality (i.e. in pay) combined with a range of interventions at each stage in the life-cycle which either contributed to or reduced inequality such as equal or differential access to childcare, early or later school selection and tracking, inequalities in types of educational institutions, inequalities in educational attainment, occupational selection mechanisms and pay returns to education.

In this analysis the UK stood out as having particularly high levels of original inequality, and in some cases institutions which either fail to narrow that inequality at crucial stages in the life cycle or exacerbate it. For example, unequal income/wealth between different families is exacerbated by a property market and housing system that sees large amounts of wealth transfer between generations in the form of property. High degrees of residential segregation and social difference between family types means that there is little mixing in preschool settings (as for instance there is in Scandinavia where most mothers work and there is comparatively integrated residential neighbourhoods). Additionally, differential income/wealth enables differential access to the education system, through the intermediary of the property market as well as the comparatively large private sector (relative to European countries). Added to this, advantage in the labour market then appears to be highly dependent not just on social connections (as the current political spat over internships suggests) but by 'cultural' and 'informational' capital: or the behaviours and soft knowledge of institutional structures and their workings (such as the University system - witness the emphasis given to personal statements in the selection process and the labour market - knowledge of what professions require particular skills and experiences). All of this coexists with significant state spending to cope with the effects of inequality, such as offsetting low wages through pay subsidies to families with children, education and health spending and the criminal justice system. Nowhere in the Strategy are significant interventions discussed that would halt these kinds of inequality in the first instance. Sure, raising school standards; better information, advice and guidance 
and the pupil premium could all ensure greater competition for places in the labour market but they are unlikely to erode the degree of advantage/disadvantage that families are able to procure for their children, without regulating the degree of overall inequality in the system. Indeed, on the contrary many of the measures suggested in the strategy may simply generate increasing inequality - such as greater autonomy for individual schools, rapidly increasing University tuition fees or reductions in the real-terms levels of welfare benefits. It is useful then to briefly pause to consider concrete Coalition Government policy announcements in the policy areas highlighted above to assess the extent to which policy interventions are becoming more or less likely to correct inequality at each stage in the life cycle.

Taken at face value the Strategy describes a wide range of measures across the life cycle that the Coalition is earnestly pursuing in support of facilitating greater mobility. Many of these are not to be dismissed outright but it is worth noting some of the contradictions. In terms of early years, the major interventions inherited by the Coalition: tax credits for low income families with children and Sure Start/Childrens' Centres. Funding for tax credits for some working families with children have been reduced considerably (Brewer 2010; Browne 2010; Browne 2011) and while the calculation of the component of local authority funding that is to support Sure Start has been maintained, ring-fencing has been removed and overall local authority budgets have been cut considerably. This then suggests that the major impact on early years services is a substantial cut back (4Children and Day Care Trust 2011). This is balanced by the promise of limited and targeted childcare for disadvantaged 2 year olds and the expansion of childcare for 3 and 4 year olds and an acknowledgement of the evidence about the importance of quality in early years settings but not about class-based mixing.

In school years, the deficit reduction process is less relevant, with funding levels largely maintained. However, the main policy initiatives are the Pupil Premium, the introduction of Free Schools and expansion of the Academies programme (Department for Education 2010), all of which are likely to lead to greater difference in the education system, rather than more universal provision - precisely the mix that is likely to lead to greater difference in educational outcomes rather than more equality.

In higher education the high profile increase in tuition fees would normally be thought to have a differential impact on access to educational opportunities for lower income groups due to differential risk aversion in educational decision making (Breen and Goldthorpe 1997). There are measures that control for this - such as universal loans, no up-front fees and a graduate tax style repayment scheme. However, high fees (in international comparative terms (see OECD 2010: Indicator B5)) are still likely to be more of a disincentive to people from low income backgrounds than middle class families with greater experience of managing debt. Moreover, the recent Higher Education White Paper suggests changes to the University admission system and student number allocation process designed to favour students with the highest marks. ${ }^{8}$ While on balance this would appear to be purely meritocratic the evidence suggests pupils from working class backgrounds and attending schools who predominantly educate working class pupils are both less likely to study at A-level and less likely to attain this profile of marks (Cabinet Office 2008: 75; Royal Society 2008).

In the domain of employment and welfare policy, changes in the administration of employment services mean that the focus on activation is being strengthened - meaning that there is less likely to be an emphasis on longer-term matching to aspirations and more emphasis on finding employment rapidly. Changes to Housing Benefit may, on the admission of senior politicians within the Coalition, may lead to greater child poverty (Boffey and Helm 2011).

Overall this quick tour of the policy domains that might be thought to have an influence on social mobility suggests that there is little emphasis being given in actual policy development to the rhetorical commitment suggested by the Strategy to even relative mobility, let alone absolute mobility. The development in many domains, such as in relation to child poverty or in relation to access to Higher Education might indeed be seen to suggest a negative future impact on relative mobility rather than a positive one (Brewer, Browne et al. 2011). 
This article argues that social mobility became a major policy issue in the UK, following the publication of a number of (contested) research reports suggesting that levels of social openness in the UK may have fallen. Alongside the counter-intuitive feel of these findings, the prominence of social mobility in media and political debate may be because it can serve as an acceptable way for the three main political parties to discuss social justice issues without questioning the political economy orthodoxy of neo-liberal competitiveness. In fact, under New Labour the policy objective of competitiveness may have always been a more important motivation than social justice. However, despite the rhetorical commitment to social mobility and competitiveness, it is suggested that the promotion of labour market participation always remained more important than did concerns with progression, potentially undermining the impact on both.

Under the Coalition Government the promotion of social mobility has apparently been given a high profile status as what the Coalition means when it says 'fairness', which in turn is held up as the counterweight to the extension of market discipline and austerity. However, the way in which social mobility is conceptualized by the Coalition demonstrates a break with New Labour's rhetorical commitment to absolute mobility. In making this break and in pursuing policies which at best may be expected to be neutral (and in several examples negative) for relative mobility, the Coalition's Strategy, is likely to be even less successful than New Labour's attempts in relation to both social openness and competitiveness. When considered in these terms the Strategy, looks ever more like an exercise in discursive legitimation of the shift away from socialization and back toward the extension of market discipline in the continued search for increased competitiveness.

This leaves the rather pregnant question of what a genuine policy to achieve social mobility might look like. Here the international evidence suggests (rather than proves) that a greater concern for equality of outcome would have a positive impact on social mobility. Greater equality appears to foster greater opportunities for short-range mobility and less risk aversion in parental strategies as a result of the lower penalties faced in the event of downward inter-generational mobility. Ironically, if combined with a concern with absolute mobility for all, this might also be better for competitiveness, ensuring that a greater proportion of the population are employed in secure, rewarding, higher paid and more productive employment.

10,483 words. $5^{\text {th }}$ October 2011.

\section{REFERENCES}

4Children and Day Care Trust (2011). 250 Sure Start Children's Centres Face Closure Within a Year. Web Story, 4Children.

Anon. (2005). Cameron v Davis on taxation, social mobility, health and Europe. The Guardian: 13.

Atkinson, R. and K. Kintrea (2001). "Disentangling Area Effects: Evidence from Deprived and Non-Deprived Neighbourhoods." Urban Studies 38(12).

BBC (2007). "Series of reports and associated documents on social mobility." The Today Programme.

Blanden, J. (2004). Changes in intergenerational mobility in Britain. Generational income mobility in North America and Europe. M. e. Corak. Cambridge, Cambridge University Press.

Blanden, J., , , (2005). "Love and Money: Intergenerational Mobility and Marital Matching on Parental Income." Research Paper, Family and Labour Studies, Statistics Canada.(272).

Blanden, J. and S. Gibbon (2006). The persistence of poverty across generations. York, JRF.

Blanden, J., P. Gregg, et al. (2005). Intergenerational mobility in Europe and North America. London, London School of Economics, Centre for Economic Performance.

Blanden, J., P. Gregg, et al. (2006). Accounting for Intergenerational Income Persistence: Non-Cognitive Skills, Ability and Education. London, Centre for the Economics of Education, London School of Economics.

Blanden, J., P. Gregg, et al. (2007). Accounting for Inter-generational Income Persistence: Non-cognitive Skills, Ability and Education. Institute for the Study of Labor, Discussion Paper. Bonn, Institute for the Study of Labor.

Blunkett, D., Ed. (2008). The Inclusive Society? Social Mobility in the 21st Century. London, Progress. 
Boas, T. and J. Gans-Morse (2009). "Neoliberalism: From New Liberal Philosophy to Anti-Liberal Slogan." Studies in Comparative International Development (SCID) 44(2): 137-161.

Boffey, D. and T. Helm (2011). "Eric Pickles warns David Cameron of rise in homeless families risk." The Observer: 1.

Breen, R. and J. H. Goldthorpe (1997). "EXPLAINING EDUCATIONAL DIFFERENTIALS: TOWARDS A FORMAL RATIONAL ACTION THEORY." Rationality and Society 9(3): 275-305.

Brewer, M. (2010). Cuts to Welfare Spending, Take 2. Slides delivered at the IFS 2010 Spending Review briefing, 21 October 2010. . London, Institute for Fiscal Studies.

Brewer, M., J. Browne, et al. (2011). Child and Working-Age Poverty from 2010 to 2020 London, Institute for Fiscal Studies.

Brown, G. (2007). Speech on Education. Speech to University of Greenwhich.

Brown, G. (2008). PM speech on education and social mobility. London, No 10 Downing Street.

Browne, J. (2010). Distributional analysis of tax and benefit changes. Slides delivered at the IFS 2010 Spending Review briefing, 21 October 2010. . London, Institute for Fiscal Studies.

Browne, J. (2011). Distributional Analysis of Tax and Benefit Changes Budget 2011 analysis and presentation slides. London, IFS.

Cabinet Office (2008). Getting on, Getting Ahead. London, Cabinet Office.

Cameron, D. (2010). Labour are now the reactionaries, we the radicals. The Guardian.

Cammack, P. (2006). "The Politics of Global Competitiveness." Papers in the Politics of Global Competitiveness 1.

Cammack, P. (2008). "Building BRICs for Global Competitiveness: the OECD and the Emerging Market Economies." Papers in the Politics of Global Competitiveness.

Cammack, P. (2009). "All Power to Global Capital." Papers in the Politics of Global Competitiveness 10.

Carrell, S. (2010). Liberal Democrats wouldn't prop up 'pointless' Labour, party strategist says. The Guardian.

Cerny, P. G. (1997). "Paradoxes of the Competition State: The Dynamics of Political Globalization." Government and Opposition 32(2): 251-274.

Clegg, N. (2010). Nick Clegg Gives Speech on Social Mobility.

Clegg, N. (2011). Social Mobility Strategy Launched. Speech at Launch of Social Mobility Strategy.

Corak, M. (2006). "Do Poor Childen Become Poor Adults? Lessons from a Cross Country Comparison of Generational Earnings Mobility." IZA Discussion Paper 1993.

Craig, D. and G. Cotterell (2007). "Periodising neoliberalism?" Policy \& Politics 35: 497-514.

d' Addio, A. (2007). "Intergenerational Transmission of Disadvantage: Mobility or Immobility across Generations? A Review of the Evidence for OECD Countries." OECD Social Employment and Migration Working Papers 52.

DCLG (2006). The Dynamics of Local Economies and Deprived Neighbourhoods. London, Department for Communities and Local Government.

Department for Education (2010). The Importance of Teaching - The Schools White Paper 2010. $\underline{\mathrm{Cm} 7980 .}$ Norwich, The Stationary Office.

Department for Innovation, U. a. S. (2007). World Class Skills: implementing the Leitch Review of Skills in England. Norwich, TSO.

Ellen, I. G. and M. Turner (1997). "Does Neighborhood Matter? Assessing Recent Evidence." Housing Policy Debate 8(4): 833-866.

Fletcher, D. R. (2008). "Tackling concentrations of worklessness: highlighting the limits of work-focused organisational cultures in the UK." Environment and Planning C-Government and Policy 26(3): 563582.

Gallie, D. (1998). Restructuring the Employment Relationship. Oxford, Oxford University Press.

Gallie, D. (2002). The Quality of Working Life in Welfare Strategy. Why we need a new Welfare State. D. Gallie and G. Esping-Andersen. Oxford, Oxford University Press.

Gallie, D. and S. Paugam (2002). Social Precarity and Social Integration: Eurobarometer 56.1. Brussels, European Commission.

Giddens, A. (2007). "You need greater equality to achieve more social mobility." The Guardian.

Goldthorpe, J. (2004). Trends in intergenerational mobility in Britain in the late Twentieth Century. Social mobility in Europe. R. Breen. Oxford, Oxford University Press.

Goldthorpe, J. H. and C. Mills (2008). Trends in Intergenerational Class Mobility in Modern Britain: Evidence From National Surveys, 1972--2005. 205: 83-100.

Goos, M. and A. Manning (2003). Lousy and Lovely Jobs. London, London School of Economics: Centre for Economic Performance. 
Harker, L. (2006). Ending Child Poverty: What would it take? A Report for the Department for Work and Pensions. Norwich, HMSO.

Harrison, J. (2007). "From competitive regions to competitive city-regions: a new orthodoxy, but some old mistakes." Journal of Economic Geography 7(3): 311-332.

HM Government (2009). New opportunities: Fair chances for the future. $\mathrm{Cm} \mathrm{7533}$. Norwich, The Stationary Office.

HM Government (2009). New Opportunities: Fair Chances for the Future. CM7533. Norwich, The Stationary Office.

HM Government (2010). The Coalition: our programme for government - Freedom, Fairness and Responsibility. London, Cabinet Office.

HM Government (2011). Opening Doors, Breaking Barriers: A Strategy for Social Mobility. London, Cabinet Office.

HM Treasury (2000). Spending Review 2000 Public Service Agreements White Paper. London, TSO.

HM Treasury (2004). Child Poverty Review. London, HM Treasury.

HM Treasury (2011). The Plan for Growth. London, Treasury.

Hogarth, T., L. Gambin, et al. (2009). Empirical Review of Employer Training. Wath-upon-Dearne, UK Commission for Employment and Skills.

Hooghe, L. and G. N. Marks (2001). Types of Multi-Level Governance, SSRN.

Houston, D. (2005). "Employability, Skills Mismatch and Spatial Mismatch in Metropolitan Labour Markets." Urban Studies 42(2): 221-243.

Hutton, J. (2006). Welfare Reform: 10 years on, 10 years ahead. speech.

IPPR (2005). Equity and Excellence: Education and Social Mobility. A keynote speech by Ruth Kelly MP, Secretary of State for Education and Skills. London.

Jæger, M. M. and A. Holm (2007). "Does parents' economic, cultural, and social capital explain the social class effect on educational attainment in the Scandinavian mobility regime?" Social Science Research 36(2): 719-744.

Johnson, A. (2006). In Defence of the State: the role of education in tackling poverty. speech to the Social Market Foundation.

Lambert, P., K. Prandy, et al. (2007). "By Slow Degrees: Two Centuries of Social Reproduction and Mobility in Britain." Sociological Research Online <http://www.socresonline.org.uk/12/1/prandy.html>. 12(1).

Leitch, S. (2006). Prosperity for all in the global economy - world class skills, Final Report. London, HMSO.

Lucas, S. R. (2001). "Effectively maintained inequality: education transitions, track mobility, and social background effects." American Journal of Sociology 106(6): 1642-1690.

Lupton, R. (2003). Neighbourhood Effects': Can we measure them and does it matter: CASE Paper 73,. London, Centre for Analysis of Social Exclusion, London School of Economics.

Narey, M. (2007). "Mind the Gap." The Guardian Society

Narey, M. (2009). Report from the Independent Commission on Social Mobility. London, Liberal Democrats.

Nunn, A. (2005). The Political Economy of Crisis and Global Governance: A thesis submitted to the University of Manchester for the degree of Doctor of Philosophy in the Faculty of Humanities. Manchester, University of Manchester.

Nunn, A. (2007). "Competitiveness and the New Labour Project " Papers in the Politics of Global Competitiveness 8.

Nunn, A. (2008). "Restructuring the English Working Class for Global Competitiveness." Papers in the Politics of Global Competitiveness 9.

Nunn, A. (2011, forthcoming). Social Mobility and Social Cohesion in European Countries. Strasbourg, Council of Europe.

Nunn, A. (2012, forthcoming). Social Mobility and Social Cohesion in European Countries. Strasbourg, Council of Europe.

Nunn, A., T. Bickerstaffe, et al. (2010). Post-Code Selection? Employers' Use of Address-Based Information Shortcuts in Recruitment Decisions, DWP Research Report. Norwich, HMSO.

Nunn, A., S. Johnson, et al. (2007). Factors Influencing Social Mobility: Department for Work and Pensions Research Report 450. Leeds, Department for Work and Pensions.

OECD (2008). Growing Unequal? : Income Distribution and Poverty in OECD Countries: COUNTRY NOTE: GERMANY Paris, OECD.

OECD (2010). Education at a Glance 2010. Paris, OECD. 
Panel on Fair Access to the Professions (2009). Unleashing Aspiration: The Final Report of the Panel on Fair Access to the Professions. London, Cabinet Office.

Peck, J., A. Tickell, et al. (2002). Neoliberalizing space: the free economy and the penal state: Spaces of Neoliberalism: Urban Restructuring in North America and Western Europe. N. Brenner and N. Theodore. Oxford, Blackwell.

Polanyi, K. (1957). The great transformation : Karl Polanyi. Boston, Beacon Press.

Power, A. (1996). "Area-based Poverty and Resident Empowerment." Urban Studies 33(9): 1535-1564.

Royal Society (2008). Exploring the relationship between socioeconomic status and participation and attainment in science education. London, Royal Society.

Sanderson, I. (2007). Worklessness and Deprived Neighbourhoods: A Review of Evidence, Report for the Neighbourhood Renewal Unit. London, DCLG.

Smith, N. and S. Middleton (2007). A review of poverty dynamics research in the UK. York, Joseph Rowntree Foundation.

Soss, J. and S. F. Schram (2007). "A Public Transformed? Welfare Reform as Policy Feedback." The American Political Science Review 101(1): 111-127.

Spiegel, P. (2011). EU presidents draft competitiveness pact. Financial Times.

Ward, K. and A. E. G. Jonas (2004). "Competitive city-regionalism as a politics of space: a critical reinterpretation of the new regionalism." Environment and Planning A 36(12): 2119-2139. 


\section{FIGURES}

FIGURE ONE

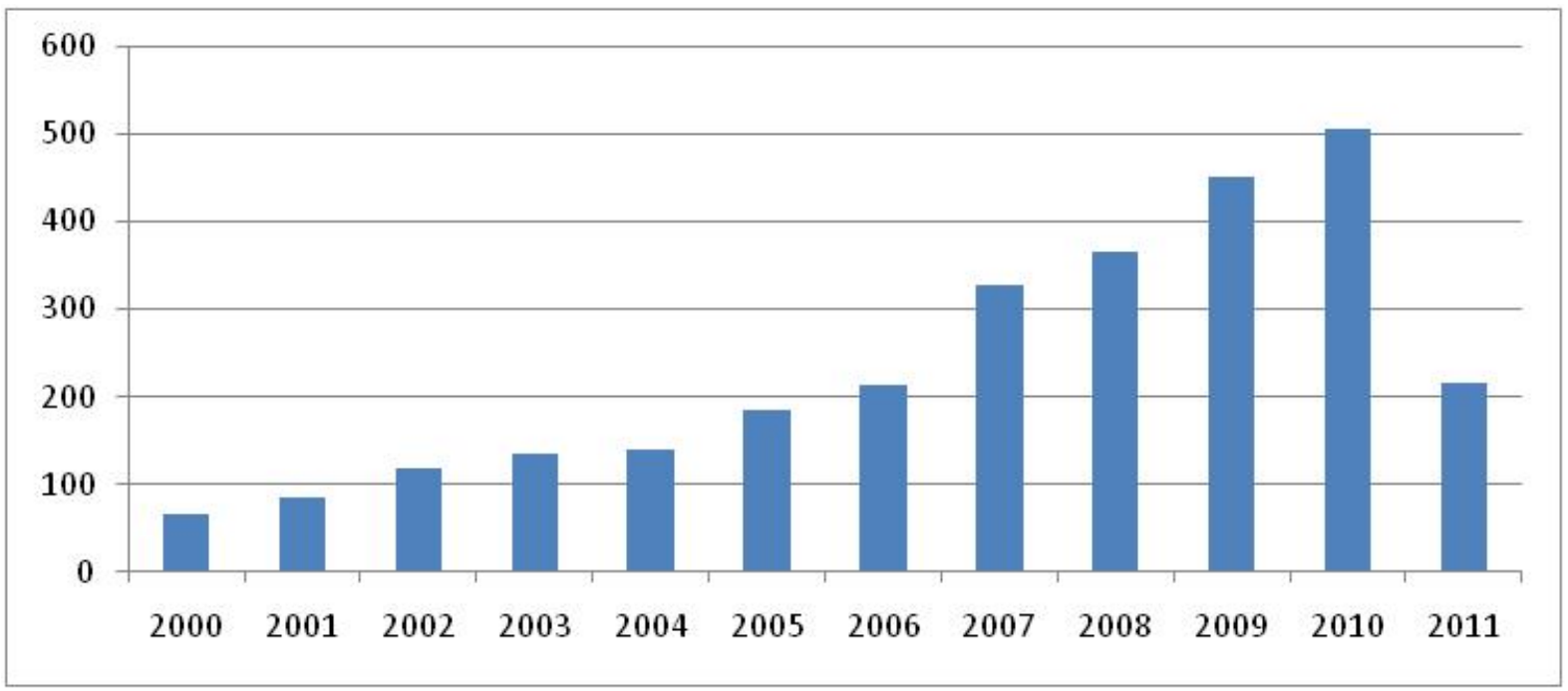

FIGURE TWO

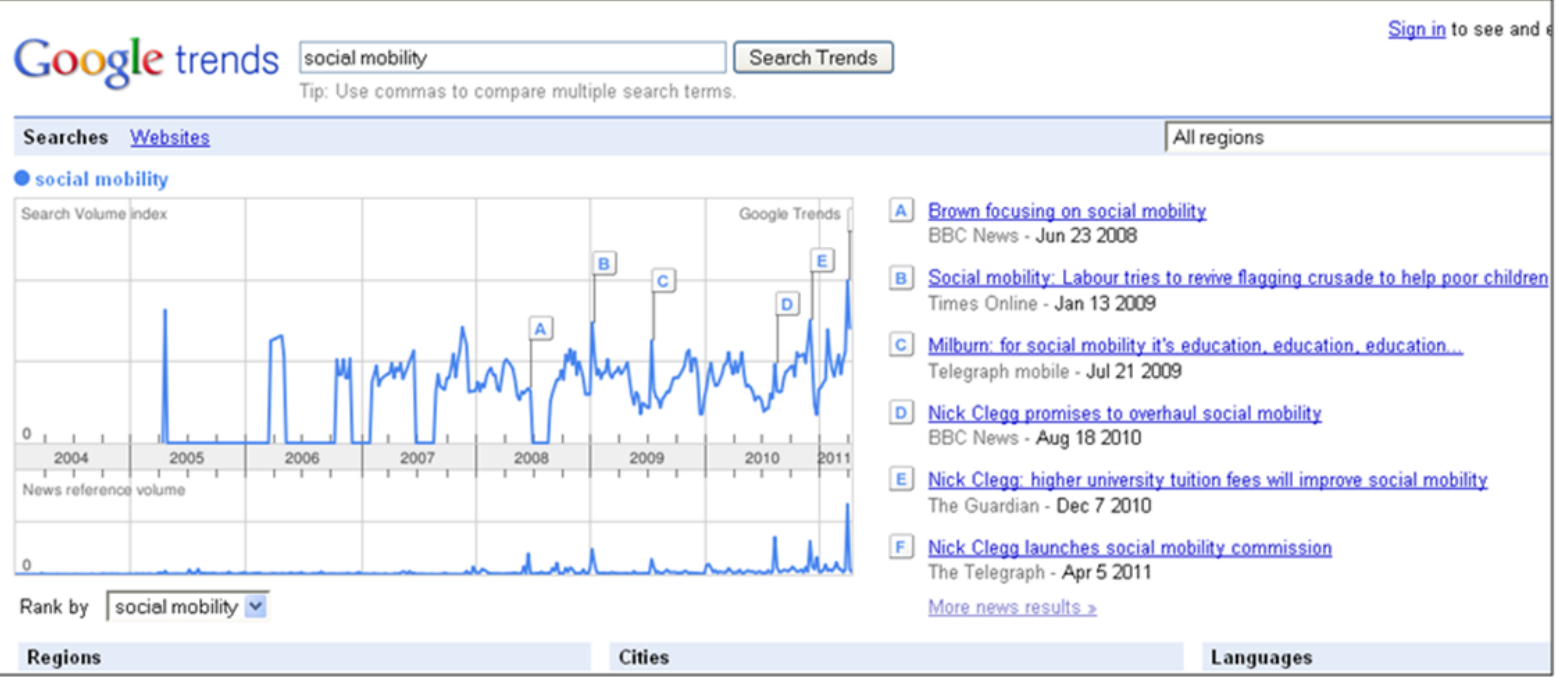




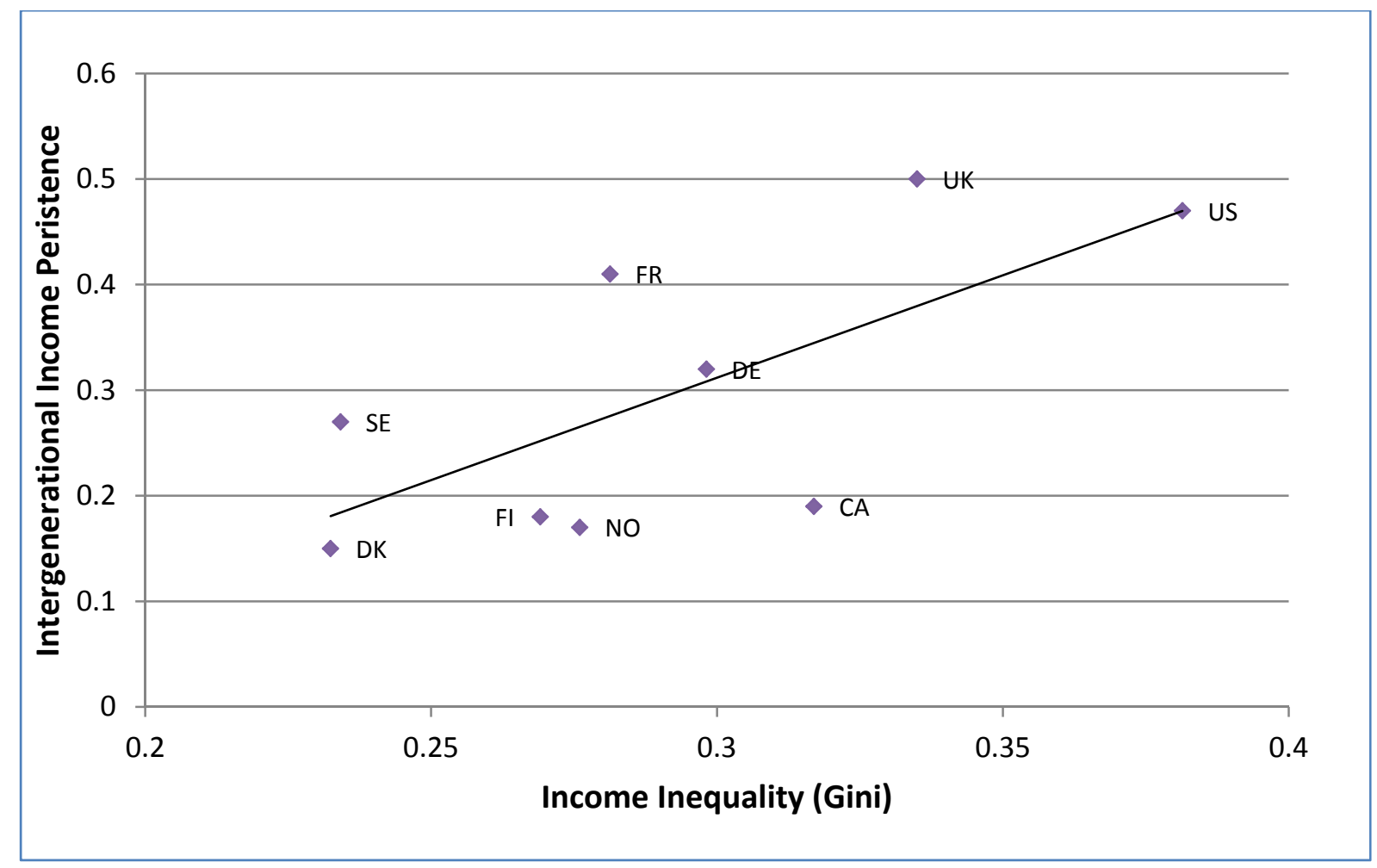

\footnotetext{
${ }^{1}$ The majority of work on social mobility is within two distinct methodological traditions: an economic tradition utilising income group analysis and a sociological tradition utilising class based models of social stratification. For a discussion of these see Nunn et al. (2007).

${ }^{2}$ Indeed Boas and Ganse-Morse Boas, T. and J. Gans-Morse (2009). "Neoliberalism: From New Liberal Philosophy to Anti-Liberal Slogan." Studies in Comparative International Development (SCID) 44(2): 137-161. comment that the term "... can mean virtually anything as long as it refers to normatively negative phenomena associated with free markets ..." (152) and “...neoliberalism has become a conceptual trash heap capable of accommodating multiple distasteful phenomena without much argument as to whether one or the other component really belongs" (156).

${ }^{3}$ Indeed the Coalition document was entitled 'Freedom, Fairness and Responsibility' where the latter referred to fiscal responsibility and discipline and the former to policies designed to row back on Anti-terrorism legislation, ID Cards and 'big government' more generally.

${ }^{4}$ Particularly 'balanced growth' referring to spatial and sectoral balance - see below for a discussion.

${ }^{5}$ e.g. White British and Black Caribbean boys in receipt of Free School Meals in terms of their GCSE performance relative to Chinese children in receipt of FSM; White Teenagers in terms of their participation in Higher Education; Ethnic Minority Graduates in terms of their recruitment to large organizations; women generally in the labour market in comparison to their educational attainment; Pakistani and Bangladeshi Woman in terms of their employment; Disabled people in relation to their employment and wages.

${ }^{6}$ Indeed, as most University admissions tutors will testify, as A-Level qualifications have inflated over time, so the conditions for access to University in the first place have increasingly also depended on these dynamics.

${ }^{7}$ This is not quite the same as the class hierarchy. There are two traditions in research on social mobility - a Sociological tradition based on Weberian notions of class and expressed largely through the allocation of class status to occupations, and an economic tradition that considers mobility within the income distribution (for a discussion see: Nunn, A., S. Johnson, et al. (2007). Factors Influencing Social Mobility: Department for Work and Pensions Research Report 450. Leeds, Department for Work and Pensions, Nunn, A. (2011, forthcoming). Social Mobility and Social Cohesion in European Countries. Strasbourg, Council of Europe.).
} 
${ }^{8} \mathrm{~A}$ level grades of $A A B$ and above. 